\title{
PERAN KEPALA SEKOLAH TERHADAP SEKOLAH RAMAH ANAK DI SMP NEGERI DI KOTA MAKASSAR
}

\author{
Ulfa Hafizah Jahidin', Supriadi Torro ${ }^{2}$ \\ 1,2Program Studi Pendidikan Sosiologi, Fakultas Ilmu Sosial, Universitas Negeri Makassar \\ jahidinulfaHaf@gmail.com ${ }^{1}$, supriaditorro@unm.ac.id ${ }^{2}$
}

\begin{abstract}
ABSTRAK
Penelitian ini bertujuan untuk mengetahui; 1) Peran kepala sekolah terhadap sekolah ramah anak di SMP Negeri di Kota Makassar. 2) Faktor Pendorong peran kepala sekolah terhadap sekolah ramah anak di SMP Negeri di Kota Makassar. 3) Faktor penghambat peran kepala sekolah terhadap sekolah ramah anak di SMP Negeri di Kota Makassar. Jenis penelitian ini merupakan penelitian kualitatif. Adapun pemilihan informan pada penelitian ini menggunakan teknik purposive sampling dengan kriteria kepala SMP Negeri di Kota Makassar yang telah terdeklarasi sebagai sekolah ramah anak. Teknik pengumpulan data yang digunakan yaitu observasi, wawancara dan dokumentasi. Teknik pengabsahan data menggunakan triangulasi sumber. Teknik analisis data melalui tiga tahap yaitu kondensasi data, model data, dan penarikan kesimpulan. Hasil penelitian ini menunjukkan bahwa: 1) Peran kepala sekolah terhadap sekolah ramah anak di SMP Negeri di Kota Makassar yaitu sebagai educator, manajer, administrator, supervisor, dan leader. 2) Faktor pendorong peran kepala sekolah terhadap sekolah ramah anak di SMP Negeri di Kota Makassar yaitu adanya motivasi atau kesadaran dari diri warga sekolah untuk mewujudkan program sekolah ramah anak dan program sekolah ramah anak yang merupakan program lanjutan dari program sebelumnya yang sudah berjalan di sekolah. 3) Faktor penghambat peran kepala sekolah terhadap sekolah ramah anak di SMP Negeri di Kota Makassar yaitu kepala sekolah yang merangkap sebagai ketua untuk berbagai kegiatan di luar dan di dalam sekolah dan alokasi dana yang kurang memadai.
\end{abstract}

Kata kunci: Peran Kepala Sekolah, Sekolah Ramah Anak

\begin{abstract}
This study aims to determine; 1) The role of school principals in child-friendly schools ini State Junior High Schools in Makassar City. 2) Factors driving the role of school principals in child-friendly schools ini State Junior High Schools in Makassar City. 3) Factors inhibiting The role of school principals in child-friendly schools ini State Junior High Schools in Makassar City. This type of research is descriptive qualitative research. The selection of informants in this study used a purposive sampling technique with the criteria of the head of a state junior high school in Makassar that had been declared as a child-friendly school. Data collection techniques used are observation, interviews and documentation. The data validation technique uses source triangulation. Data analysis techniques through three stages, namely data condesation, data models, and drawing conclusions. The results showed that; 1) The role of schoo principals in child-friendly schools in State Junior High Schools in Makassar City is as educators, managers, administration, supervisors, and leaders. 2) Factors driving the role of school principals in child-friendly schools ini State Junior High Schools in Makassar City are the motivation or awareness of the school community to realize a child-friendly school program and a child-friendly school program which is a continuation of previous programs that have been running at school. 3) Factors inhibiting The role of school principals in child-friendly schools ini State Junior High Schools in Makassar City are principals who also act as leaders for various activities outside and inside the school and inadequate allocation of funds.
\end{abstract}

Keywords: The Role of School Principals, Child Friendly Schools

\section{PENDAHULUAN}

Sekolah merupakan salah satu tempat pendidikan yang bersifat formal untuk menimba ilmu. Selain itu, sekolah juga merupakan salah satu tempat yang sangat berpengaruh untuk pembentukan karakter seorang anak selain keluarga dan lingkungan masyarakat. Sekolah juga dijadikan sebagai tempat berkumpul dan bermain bagi anak bersama temannya. 
Sekolah adalah suatu lembaga atau institusi yang dirancang untuk pengajaran siswa atau murid di bawah pengawasan para pendidik yang memiliki sistem dan struktur yang berkesinambungan untuk mencapai tujuan yang telah dirancang. Para pendidik dan tenaga kependidikan memiliki peran penting yakni mampu memfasilitasi siswa dalam pembelajaran dan menyelenggarakan pendidikan sebagaimana mestinya. Sekolah harus memberikan rasa aman dan nyaman bagi siswa untuk menuntut ilmu dan melakukan aktivitas pendidikan lainnya. Penciptaan lingkungan yang tentram, siswa akan mudah berkreasi dan bebas belajar mengekspresikan dirinya tanpa tertekan dan merasa takut. (Satriah, Tajiri, \& Yuliani, 2019)

Peran tenaga pendidik seperti guru, tenaga administrasi, kepala sekolah sangat diperlukan dalam mewujudkan tujuan pendidikan nasional yang telah disusun. Terkhusus kepala sekolah yang memiliki dua tugas sekaligus, selain sebagai guru yang mengajar siswa dalam proses belajar mengajar, kepala sekolah juga memiliki peran penting yang memiliki tanggung jawab terhadap aplikasi prinsip-prinsip administrasi pendidikan yang inovatif di sekolah. Hal ini mengacu pada pengertian "kepala sekolah yaitu guru yang mendapat tugas tambahan sebagai kepala sekolah"(Awaru, 2015).

Sekolah ramah anak adalah "pendekatan UNICEF untuk mempromosikan pendidikan secara berkualitas di sekolah untuk semua anak, terutama dikalangan yang paling rentan dan sulit dijangkau polusi baik dalam keadaan sehari-hari dan keadaan darurat"(Sakti, 2016). Sekolah ramah anak merupakan program yang disosialisasikan oleh Dinas Pendidikan dan Kebudayaan (Disdikbud) ke sekolah-sekolah. Hal ini diperuntukkan untuk menghidupkan rasa aman, nyaman, dan bebas kepada anak untuk berkreasi dalam proses pembelajaran di sekolah, sehingga diharapkan meningkatkan prestasi belajar bagi anak.

Program sekolah ramah anak sudah disosialisasikan disetiap sekolah di Kota Makassar. Namun masih banyak sekolah yang belum mampu merealisasikan indikatorindikator program sekolah ramah anak ini, hanya beberapa sekolah yang sudah terdeklarasi sebagai sekolah ramah anak. Pedeklarasian sekolah ramah anak berisikan tentang poinpoin penting yang harus dipenuhi setiap sekolah seperti yang sudah dijelaskan yakni menjamin pemenuhan dan perlindungan hak-hak anak., mendukung partisipasi anak dalam prencanaan, kebijakan, pembelajaran dan pengawasan, dan juga mempunyai mekanisme pengaduan terkait pemenuhan dan perlindungan hak anak di sekolah. Sekolah-sekolah yang sudah terdeklarasi sebagai sekolah ramah anak di Kota Makassar di antaranya SMP Negeri 3 Makassar, SMP Negeri 30 Makassar, dan SMP Negeri 6 Makassar. Pencapaian pemenuhan indikator-indikator sekolah ramah anak dibeberapa sekolah tersebut tentu tidak terlepas dari inovasi dan dukungan dari kepala sekolah, guru, orangtua, dan juga peserta didik itu sendiri (Torro, 2019) (Ratna \& Torro, 2019).

Jika melihat jauhnya perbandingan jumlah SMP secara keseluruhan dan SMP yang telah mendeklarasikan dirinya sebagai sekolah ramah anak yang masih sangat sedikit, dapat disimpulkan jika dalam penerapan sekolah ramah anak ini tidaklah mudah dan banyak menemui kesulitan. Kepala sekolah selaku pemimpin sekolah pasti memiliki peran penting dalam pelaksanaan, tanggung jawab atas kebijakan dan program yang telah dibuat dan direncanakan terkhusus tercapainya program sekolah ramah anak. Mengingat kepala sekolah sebagai pemengang kebijakan tertinggi juga penentu arah jalannya kebijakan sebuah sekolah. Tujuan penelitian ini adalah untuk mengetahui peran kepala sekolah terhadap sekolah ramah anak, faktor Pendorong peran kepala sekolah terhadap sekolah ramah anak, dan faktor penghambat peran kepala sekolah terhadap sekolah ramah anak di SMP Negeri di Kota Makassar 


\section{METODE PENELITIAN}

Jenis penelitian ini adalah kualitatif deskriptif yakni "deskriptif, data yang dikumpulkan lebih mengambil bentuk kata-kata atau gambar daripada angka-angka. Hasil penelitian tertulis berisi kutipan-kutipan dari data untuk mengilustrasikan dan menyediakan bukti presentasi.(Gunawan, 2013) Teknik dalam menentukan informan menggunakan purposive sampling yaitu "pemilihan siapa subjek yang ada dalam posisi terbaik untuk memberikan informasi yang dibutuhkan". Informan yang berjumlah 6 orang, adapun kriteria informan yaitu kepala sekolah menengah pertama yang telah terdeklarasi sebagi sekolah ramah anak di Kota Makassar. Teknik pengumpulan data yang digunakan yaitu observasi, wawancara, dokumentasi. Teknik analisis data kualitatif tipe dekskriptif melalui tiga tahap yaitu kondensasi data, model data data dan penarikan kesimpulan.(Upe, n.d.) Teknik pengabsahan data melalui triangulasi sumber yaitu "suatu cara mendapatkan data yang benar-benar absah dengan menggunakan pendekatan metode ganda"

\section{HASIL PENELITIAN DAN PEMBAHASAN}

\section{Peran Kepala Sekolah Terhadap Sekolah Ramah Anak Di SMP Negeri di Kota Makassar}

Pembahasan ini mengenai peran kepala sekolah terhadap sekolah ramah di SMP Negeri di Kota Makassar. berdasarkan penelitian yang telah dilakukan, penulis menemukan bahwa kepala sekolah telah menjalankan perannya sebagai educator, manajer, administrator, supervisor, dan leader terkait dengan program sekolah ramah anak. Peran kepala sekolah terhadap sekolah ramah anak di SMP Negeri di Kota Makassar yang pertama yaitu sebagai educator. Pendidik adalah orang yang memberikan pendidikan, pengajaraan, serta pembinaan. Pendidik mempunyai tanggung jawab untuk mendidik, membina, dan mempengaruhi orang lain untuk mampu memahami dan mengetahui sesuatu hal. Kepala sekolah sebagai pendidik berkaitan dengan perannya menyusun strategi perencanaan, memberikan nasehat dan dorongan kepada warga sekolah, dan membina warga sekolah. Sehubungan degan program sekolah ramah anak yang berjalan di sekolah, kepala sekolah sebagai pendidik memiliki peran bagaimana membina dan mendidik warga sekolah termasuk guru, siswa, dan para staf sekolah lainnya agar memahami program sekolah ramah anak ini.

Dari hasil penelitian ditemukan bahwa kepala sekolah sebagai pendidik menjalankan perannya dengan membina dan mendidik warga sekolah secara langsung terkait dengan program-program sekolah yang berjalan terkhususnya program sekolah ramah anak. Cara pembinaan yang diberikan oleh kepala sekolah kepada warga sekolah lainnya ialah dengan memberikan wejangan atau nasehat dan selalu mengingatkan warga sekolah untuk tetap patuh pada aturan sekolah agar tercipta lingkungan sekolah yang kondusif. Pembinaan yang dilakukan oleh kepala sekolah biasanya dilakukan pada saat rapat atau pertemuan khusus yang diadakan untuk membahas program sekolah ramah anak dan pada saat proses belajar mengajar berlangsung. Ini berkaitan dengan artian kepala sebagai educator yakni "mengajar di kelas, membimbing guru, membimbing karyawan, mengembangkan staf, mengikuti perkembangan IPTEK, dan memberi contoh bimbingan konseling/karier yang baik".

Peran kepala sekolah terhadap sekolah ramah anak di SMP Negeri di Kota Makassar yang kedua yaitu sebagai manager. Manager pada dasarnya merupakan suatu proses merencanakan strategi, mengendalikan para anggotanya, serta memberdayakan para anggotanya agar memudahkan mencapai tujuan yang telah ditetapkan. Dalam hal kepala 
sekolah sebagai manajer, kepala sekolah sekolah memiliki peran dengan membuat strategi yang efektif untuk memberdayakan warga sekolah terkait dengan program sekolah yang berjalan, memberikan kesempatan bagi tenaga pendidik untuk meningkatkan profesionalitasnya yang menunjang keberhasilan program sekolah.

Dari hasil penelitian ditemukan bahwa kepala sekolah sebagai manager telah menjalankan tugasnya sebagaimana mestinya dengan memberdayakan para warga sekolah yakni para staf, guru, komite sekolah, dan para siswa. Bentuk pemberdayaan yang dilakukan oleh kepala sekolah ialah dengan mengadakan sosialisasi terkait program sekolah ramah anak serta melakukan pertemuaan atau rapat mengenai sekolah ramah anak. Selain itu juga, kepala sekolah sebagai manajer mengikutkan guru-guru pada pelatihan yang diadakan oleh Dinas Pemberdayaan Perempuan dan Perlindungan Anak guna meningkatkan pengetahuannya konveksi hak-hak anak.

Peran kepala sekolah terhadap sekolah ramah anak di SMP Negeri di Kota Makassar yang ketiga yaitu sebagai administrator. Administrasi merupakan kegiatan atau usaha yang berkenaan dengan cara perencanaan, pengorganisasian, pembagian tugas, serta mengkoordinir untuk mencapai sebuah tujuan. Kepala sekolah sebagai administrator dalam pelaksanaan program sekolah ramah anak berkaiatan dengan cara menyusun organisasiorganisasi sekolah, cara mengkoordinator warga sekolah, dan menyusun pembagian tugas kepada guru mengenai pembinaan organisasi-organisasi sekolah ramah anak.

Berdasarkan dari penelitian yang telah dilakukan diketahui bahwa kepala sekolah sebagai administrator telah terlaksana sesuai dengan program sekolah ramah anak. Kepala sekolah membentuk organisasi dengan memilih guru terlatih sebagai Pembina dan siswa yang menjadi angotanya. Selanjutnya kepala sekolah mengkoordinir dengan memastikan warga sekolah saling bekerja sama dalam mewujudkan program sekolah ramah anak. Terakhir, kepala sekolah melakukan pembagian tugas kepada guru terkait sekolah ramah anak sesuai dengan kemampuan guru terkait hak-hak anak. Hal ini berkenaan dengan kepala sekolah sebagai administrator dengan tugas "membuat perencanaan, menyusun organisasi sekolah, kepala sekolah sebagai administrator pendidikan perlu menyusun organisasi sekolah yang dipimpinnya, bertindak sebagai koordinator dan pengarah, dan melaksanakan pengelolaan kepegawaian.

Peran kepala sekolah terhadap sekolah ramah anak di SMP Negeri Kota Makassar yang keempat yaitu sebagai supervisor. Supervisi ialah kegiatan melihat dan mengawasi orang bawahan atau yang memiliki jabatan rendah yang dilakukan orang atasan atau orang yang memiliki jabatan tinggi. Kepala sekolah sebagai supervisor jika dihubungkan dengan sekolah ramah anak maka perannya yakni bagaimana bentuk pengawasan yang dilakukan kepada warga sekolah menjalakan serta mewujudkan program sekolah ramah anak di sekolah. (Pujayanti, 2006)

Berdasarkan hasil penelitian diketahui bahwa kepala sekolah sebagai supervisor melaksanakan tugasnya dengan melakukan pengawasan terkait pelaksanaan sekolah ramah anak di sekolah. Pengawasan yang dilakukan oleh kepala sekolah terbagi menjadi dua cara yakni secara langsung dan tidak langsung. Pengawasan secara langsung dilakukan dengan cara kepala sekolah mendatangi langsung tempat aktivitas dan kegiatan sekolah, berkeliling sekolah, memastikan secara langsung kebersihan sekolah, mendatangi kelas, kantin, dan ruang sekolah lainnya. Sedangkan secara tidak langsung dilakukan dengan mengawasi melalui media elektronik seperti handphone dan CCTV. Hal ini berkenaan dengan pertanyaan yang mengatakan bahwa kepala sekolah yang menjalankan tugasnya sebagai supervisor yakni melakukan pengawasan yakni "pengontrolan agar kegiatan pendidikan di sekolah terarah pada tujuan ang telah ditetapkan dan tindakan preventif 
untuk mencegah agar para tenaga kependidikan tidak melakukan tindakan penyimpangan dan lebih berhati-hati dalam melaksanakan pekerjaannya".

Peran kepala sekolah terhadap sekolah ramah anak di SMP Negeri di Kota Makassar yang kelima yaitu sebagai leader. Pemimpin atau leader adalah individu yang memiliki kekuatan atau power yang mampu mengarahkan, mempengaruhi bawahannya agar melakukan suatu tindakan untuk mencapai sebuah tujuan yang telah ditetapkan. Seorang pemimpin memiliki tanggung jawab akan setiap yang dilakukan anggotanya. Kepala sekolah sebagai pemimpin harus mampu mengarahkan dan memberi atau menjelaskan petunjuk mengenai prosedur program-program yang berjalan di sekolah, sehingga para warga sekolah akan terstruktur menjalakan tugasnya masing-masing.

Berdasarkan hasil penelitian diketahui bahwa peran kepala sekolah sebagai pemimpin telah terpenuhi dengan kepala sekolah melaksanakan dengan memberikan arahan dan menjelaskan petunjuk terkait prosedur pelaksanaan sekolah ramah anak terhadap warga sekolah yang biasa diberikan pada saat upacara dan sebagainya. Hal ini sejalan dengan "kepala sekolah sebagai pemimpin harus mampu memberikan petunjuk dan pengawasan, meningkatkan kemauan tenaga kependidikan, membuka komunikasi dua arah, dan mendelegasikan tugas".

Terkait dengan salah satu teori yang dipakai oleh penelitian ini yakni teori peran yang mengatakan bahwa setiap individu memiliki status yang harus memenuhi perannya dengan menjalankan kewajiban-kewajiban yang diharapkan oleh perannya tersebut. Kepala sekolah merupakan status yang memiliki beberapa peran yaitu sebagai pemimpin, pendidik, manajer, administrator, dan supervisor. Di dalam penelitian ini telah diperoleh informasi bahwa kepala sekolah telah memenuhi kewajiban-kewajibannya sesuai dengan harapan perannya masing-masing. Hal yang sama ditunjukkan oleh hasil penelitian ini yang menunjukkan bahwa kepala sekolah melaksanakan perannya sebagai manajer dengan mengadakan pelatihan dan sosialisasi terkait program sekolah ramah anak, sebagai pemimpin dengan melaksanakan kebijakan SRA, sebagai administrator dengan membentuk organisasi yang melibatkan siswa dan guru, dan sebagai supervisor dengan melakukan pengawasan terkait program dan kurikulum yang berjalan.

\section{Faktor Pendorong Peran Kepala Sekolah Terhadap Sekolah Ramah Anak Di SMP Negeri di Kota Makassar}

Faktor pendorong merupakan hal-hal yang sifatnya turut menjadi pendukung, membantu, menunjang dan melancarkan suatu proses kegiatan. Peran kepala sekolah terhadap sekolah ramah anak di SMP Negeri di Kota Makassar didorong oleh dua faktor yaitu adanya motivasi atau dorongan kesadaran dari dalam diri warga sekolah dan program SRA merupakan program lanjutan dari program sebelumnya. Yang pertama yang menjadi faktor pendorong peran kepala sekolah terhadap sekolah ramah anak di SMP Negeri di Kota Makassar yaitu adanya motivasi atau dorongan kesadaran diri dari dalam warga sekolah. Menurut Mc Donald motivasi adalah 'suatu perubahan energi di dalam pribadi seseorang yang ditandai dengan timbulnya afektif (perasaan) dan reaksi untuk mencapai tujuan". Motivasi adalah dorongan yang timbul untuk melakukan suatu hal demi mencapai tujuan tertentu. Para personil sekolah memiliki motivasi atau dorongan dari kesadaran mereka akan pentingnya program sekolah ramah anak ini diimplementasikan di sekolah. Terlaksananya program ini akan membuat sekolah mencapai kondisi yang ideal dan bagus untuk seluruh personil sekolah. Berdasarkan hasil penelitian dapat diketahui salah satu faktor pendorong terlaksananya program sekolah ramah anak di sekolah adalah adanya motivasi atau dorongan kesadaran diri dari dalam warga sekolah. 
Yang kedua yang menjadi faktor pendorong peran kepala sekolah terhadap sekolah ramah anak di SMP Negeri di Kota Makassar yaitu program SRA merupakan program lanjutan dari program sebelumnya. Setiap sekolah sebenarnya sudah memiliki peraturan tata tertib yang ada seperti dilarang adanya kekerasan di sekolah, selalu menjaga kebersihan lingkungan sekolah, selalu bekerja sama, menjaga keharmonisan antar warga sekolah, dan sebagainya yang menunjang keberhasilan sebuah pendidikan di lingkungan sekolah. Munculnya program sekolah ramah anak ini tidak menjadi kendala besar untuk diimplementasikan karena ditinjau lagi dari beberapa indikator pencapaian pelaksanaannya sekolah sudah lama menerapkan hal tersebut. Berdasarkan dari penelitian yang telah dilaksanakan dapat diketahui bahwa salah satu faktor pendorong peran kepala sekolah terhadap sekolah ramah anak di SMP Negeri di Kota Makassar yaitu program sekolah ramah anak merupakan program lanjutan dari program sekolah sebelumnya sehingga tidak sulit bagi program ini diimplementasikan oleh warga sekolah di lingkungan sekolah.

Salah satu teori yang digunakan oleh penelitian ini yaitu teori struktural fungsional Talcott Parsons, yang terkenal dengan konsep AGIL yang menjadi syarat sebuah sistem dapat bertahan. Dalam kaitan dengan penelitian ini, sekolah dipandang sebagai sebuah sistem yang memiliki beberapa elemen-elemen yang memiliki fungsi masing-masing dan saling berkaitan satu sama lain. Elemen-elemen tersebut ialah para personil sekolah yakni kepala sekolah, guru, staf administrasi, orangtua, masyarakat, dan juga siswa. Bila elemenelemen yang ada dalam suatu sistem menjalankan fungsinya masing-masing maka sistem tersebut akan bertahan dan mencapai tujuannya yang telah direncanakan. Dalam pembahasan faktor pendorong peran kepala sekolah terhadap sekolah ramah anak di SMP Negeri di Kota Makassar, dapat dinyatakan bahwa para personil sekolah yakni elemen dalam sistem melaksanakan fungsinya masing-masing sehingga sekolah dapat menjalankan programnya sebagaimana mestinya.

Berhubungan dengan penelitian terdahulu yang dilakukan oleh (Ahmad \& Muharom, 2017) Hasil penelitian tersebut menunjukkan bahwa upaya kepala sekolah SDIT Nur Hidayah untuk mewujudkan sekolah ramah anak di antaranya adalah mengadakan pelatihan guru terkait hak-hak anak, melakukan pengawasan pelaksanaan kurikulum atau kegiatan sekolah, melaksanakan kebijakan SRA, dan memberikan ruang partisipasi kepada siswa. Hal ini berbeda dengan yang ditunjukkan oleh hasil penelitian ini yang membahas bahwa faktor pendorong kepala sekolah terhadap sekolah ramah anak di SMP Negeri di Kota Makassar yakni adanya motivasi atau kesadaran dari dalam diri personi sekolah untuk mewujudkan peran ini dan program SRA yang merupakan program lanjutan dari program yang sudah berjalan lebih dulu di sekolah-sekolah.

\section{Faktor Penghambat Peran Kepala Sekolah Terhadap Sekolah Ramah Anak Di SMP Negeri di Kota Makassar}

Faktor penghambat ialah semua hal-hal yang sifat menghambat atau bahkan menahan atau mengahalangi terjadinya sesuatu. Berkaitan dengan peran kepala sekolah terhadap sekolah ramah anak di SMP Negeri di Kota Makassar terdapat beberapa faktor penghambat yang ditemui yaitu kepala sekolah yang merangkap sebagai ketua untuk berbagai kegiatan di luar dan di dalam sekolah dan alokasi dana yang kurang memadai.

Faktor pertama yang menjadi penghambat peran kepala sekolah terhadap sekolah ramah anak di SMP Negeri di Kota Makassar yaitu kepala sekolah yang merangkap sebagai ketua untuk berbagai kegiatan di luar dan di dalam sekolah. Kepala sekolah yang memiliki berbagai peran tentunya tidak akan hannya bisa fokus pada satu perkerjaan saja. Ada banyak kegiatan dan program yang berkaitan dengan sekolah yang hanya bisa 
dilakukan oleh kepala sekolah itu sendiri. Pada saat kepala sekolah melaksanakan kewajibannya terutama pada saat di luar sekolah, maka kegiatan yang berlangsung di dalam sekolah akan diwakilkan oleh wakil kepala sekolah.

Faktor kedua yang menjadi penghambat peran kepala sekolah terhadap sekolah ramah anak di SMP Negeri Kota Makassar yaitu alokasi dana yang kurang memadai. Berbicara tentang dana pasti akan ditemui sebagai penghambat akan berjalannya berbagai kegiatan. Tidak menutup kemungkinan dengan pelaksanaan peran kepala sekolah terhadap sekolah ramah anak di SMP Negeri di Kota Makassar, banyaknya program dan kegiatan di sekolah tidak akan terpenuhi dengan minimnya dana sekolah. Pembagian anggaran dana yang tidak teratur atau tidak tepat sasaran akan berpengaruh pada prosedur pelaksanaan program dan kegiatan yang akan berlangsung sekolah.

Salah satu teori yang digunakan dalam penelitian ini ialah teori struktural fungsional dengan konsep AGIL, yang menyatakan bahwa sebuah sistem dapat bertahan apabila elemen-elemen dalam sistem tersebut menjalankan fungsinya masing-masing. Berkaitan dengan penelitian ini, sekolah dipandang sebagai sebuah sistem dan para personil sekolah seperti kepala sekolah, guru, orangtua, staf administrasi, masyarakat, dan siswa dipandang sebagai elemen yang harus saling berkaitan. Dari pembahasan ini, faktor penghambat peran kepala sekolah terhadap sekolah ramah anak di SMP Negeri di Kota Makassar, ada beberapa kendala yang ditunjukan dari kepala sekolah itu sendiri. Ini menunjukkan jika elemen-elemen yang tidak dapat menjalankan fungsinya sebagaimana mestinya akan menghambat berjalannya sistem tersebut. Dari hasil penelitian ini menyatakan bahwa ada beberapa hambatan yang menghalangi peran kepala sekolah menjalan program sekolah ramah anak yakni kepala sekolah sendiri merangkao sebagai ketua untuk berbagai kegiatan di luar maupun di dalam sekolah dan alokasi dana yang kurang memadai membatasi kepala sekolah untuk melaksanakan perannya sebagaimana mestinya.

Hasil penelitian (Ahmad \& Muharom, 2017) menunjukkan bahwa upaya kepala sekolah SDIT Nur Hidayah untuk mewujudkan sekolah ramah anak di antaranya adalah mengadakan pelatihan guru terkait hak-hak anak, melakukan pengawasan pelaksanaan kurikulum atau kegiatan sekolah, melaksanakan kebijakan SRA, dan memberikan ruang partisipasi kepada siswa. Hasil penelitian tersebut menunjukkan bahwa upaya kepala sekolah SDIT Nur Hidayah untuk mewujudkan sekolah ramah anak di antaranya adalah mengadakan pelatihan guru terkait hak-hak anak, melakukan pengawasan pelaksanaan kurikulum atau kegiatan sekolah, melaksanakan kebijakan SRA, dan memberikan ruang partisipasi kepada siswa. Hal ini berbeda dengan yang ditunjukkan oleh hasil penelitian ini yang membahas bahwa faktor penghambat kepala sekolah terhadap sekolah ramah anak di SMP Negeri Kota Makassar yakni kepala sekolah yang merangkap sebagai ketua untuk berbagai kegiatan di luar dan di dalam sekolah dan alokasi dana yang kurang memadai.

\section{PENUTUP}

Berdasarkan rumusan masalah yang diangkat dalam penelitian ini. Kesimpulannya adalah peran kepala sekolah terhadap sekolah ramah anak di SMP Kota Makassar yaitu sebagai educator, administrator, manajer, supervisor, dan leader, faktor pendorong peran kepala sekolah terhadap sekolah ramah anak di SMP Kota Makassar yaitu adanya motivasi atau kesadaran dari diri warga sekolah untuk mewujudkan program sekolah ramah anak dan program sekolah ramah anak yang merupakan program lanjutan dari program sebelumnya yang sudah berjalan di sekolah, dan faktor penghambat peran kepala sekolah terhadap sekolah ramah anak di SMP Negeri Kota Makassar yaitu kepala sekolah yang 
merangkap sebagai ketua untuk berbagai kegiatan di luar dan di dalam sekolah dan alokasi dana yang kurang memadai.

\section{DAFTAR PUSTAKA}

Ahmad, S., \& Muharom, F. (2017). Upaya Kepala Sekolah dalam Mewujudkan Sekolah Ramah Anak Di SDIT Nur Hidayah Surakarta Tahun Pelajaran 2016/2017. IAIN Surakarta.

Awaru, O. T. (2015). Pengaruh Gaya Kepemimpinan Transaksional Dan Transformasional Terhadap Kinerja Guru SMA Di Kabupaten Sinjai. Jurnal Ad'ministrare, 2(1), 27-35.

Gunawan, I. (2013). Metode penelitian kualitatif. Jakarta: Bumi Aksara, 143.

Pujayanti, N. (2006). Peranan kepala sekolah sebagai supervisor dalam pengembangan staf dan kurikulum (Studi Kasus di SMP Negeri 11 Tangerang, Banten). Universitas Negeri Semarang.

Ratna, R., \& Torro, S. (2019). Implementasi Sekolah Raman Anak di SMAN 3 Makassar. JURNAL SOSIALISASI, 111-116.

Sakti, B. P. (2016). Indikator Sekolah Dasar Ramah Anak. Prosiding Seminar Nasional PKO FKIP UTP, 163-176.

Satriah, L., Tajiri, H., \& Yuliani, Y. (2019). Parenting skills untuk membangun karakter anak: Aplikasi dakwah melalui bimbingan kelompok. Prodi Manajemen Dakwah.

Torro, S. (2019). Kontribusi Komite Sekolah Terhadap Pelaksanakan Sekolah Ramah Anak Pada SMP di Kabupaten Takalar. Seminar Nasional LP2M UNM.

Upe, A. (n.d.). Damsid. 2010. Asas-Asas Multiple Researches: Dari Norman K. Denzin Hingga John W. Creswell Dan Penerapannya. 